\title{
Global Managerial Resources and the Choice of Entry Mode for International Expansion: A Test of Penrosean Resource-Based Perspective
}

\author{
CHUL WOO MOON
}

School of Business, Sungkyunkwan University

\begin{abstract}
Linking the Penrosean resource-based view (RBV) to firm's mode choice decision for entering into international markets, this papet proposes a dynamic model of mode choice based on the Penrosean resource-based theory. Specifically, the model suggests that firm's managerial resource developed for a particular mode (e.g., international acquisitions or alliances) in the past will affect the firm's subsequent choice of governance mode in the future. An empirical test based on a sample of U.S. Firms international scrategic combination activities generally supported the adequacy of the proposed Penrosean model.
\end{abstract}

Keywords: Penrosean perspective, entry mode choice, transaction cost economies (TCE), resuurce-based view (RBV), mode specific resources

\footnotetext{
* I am grateful to Anil Gupta at the Eniversity of Maryland for his helpful feedback on earlier versions of this manuscript.

Direct all correspondence to Clul Woo Moon, Associate Professor of School of Business, Sungkyunkwan University, 53 Mycongnyun-dong 3-ga, Jongno-gu, Seoul 110-745, Kotea; Tel: 82-2-760-0625; E-mail: cwmoon(a)skkı.edu
} 


\section{INTRODUCTION}

W hen a firm enters into a foreign market, a fundamental question it faces is, under what conditions the firm should pursue a hierarchical governance mode such as a fully-owned subsidiary, and under what other conditions it should pursue such quasi-hierarchical governance modes as joint ventures and alliances? While entry mode decision has received much research attention in the literature, this paper attempts to make a contribution to the extant literature by pursuing the following researcly question: what additional explanation(s) can the resource-based view of the firm (RBV) offer to the entry mode decision between hieratchy and quasi-hierarchy?

Entry mode decision for international expansion has so far been analyzed predominantly from the perspective of transaction cost economics (TCE). TCE-based perspective posits that, when the markers for the intermediate resources (e.g., raw material, components, distribution channels) held by both firms fail simultancously, governing the transactions of such resources under arm's length market exchange or contractual agreement would entail high transactional hazards. Assuming opportunistic behavior of the involved parties, the TCF. views that, in case of market failures, transactional hazards will increase (e.g., taking advantage of the other party by charging inflated prices, or deliberately reducing the quality of the resources being transferred) (Gatignon and Anderson 1986; Gatignon and Anderson 1988; Gomes-Casseres 1989; Hennart 1991). Further, the ICE argues that as the cost of preventing and coping with such opportunistic behavior and transactional hazards increases, firms are better off by internalizing the transactions under their own hierarchy, replacing market as the governance mechanism (Williamson 1985).

Specifically, the TCE literature indicates that such market failures are likely in the following situations: (1) when the resources to be transferred are intangible resources with tacit nature, such as proprietary technical know-how, reputation, management skills (Alchian and Demsetz 1972; Arrow 1974; Teece 1981; Gatignon and Anderson 1988; Gomes-Casscres 1989; Hennare 1991); (2) when the transactions are likcly to require exchange of pxersonnel and responses to contingencies that arce ex ante difficult to predict (Williamson 1985; Teece 1981; Gomes-Casseres 1989); (3) when there exists the potential for externalities that affect the remaining operations of the donor firm (Williamson 1985; Gomes-Casscres 1989); and (4) when the firms need to make investments in resources that are specific to the relationship (Williamson 1985; Gomes-Casseres 1989). Hence, underlying such TCE-based explanation of governance mode choice is the conceptualization of the firm as "a nexus of contracts" (Williamson 1985).

More recent developments in the entry mode research further identify the following as important determinants of entry mode choice: asymmetric information and digestibility (Hennart and Reddy 2000), institutional and cultural factors (Brouthers and Brouthets 2000; Brouthers 2002), firm's international strategy (Harzing 2002), CEO successor characteristics (Herrmann and Datta 2002), isomorphism (Davis, Desai and Francis 2000), market barriers and firm capabilities (Chen and Hennart 2002), and intra- 
and inter-organizational imitarive behavior (Lu 2002).

\section{RBV Perspective on Entry Mode Choice}

The resource-based view (RBV) conceptualizes the firm as a collection of productive resources (Penrose 1959; Wernetfelt 1984; Barney 1991). RBV, as a theory of firm, is essentially concerned with the search for and sustainability of economic rents (Mahoney 1995). Within RBV, the concept of rent kefers to returns accruing to hard-to-copy, which are firm-specific resources and capabilities (Castanias and Helfat 1991; Peteraf 1993; Rumelt 1987). Further, in order to form the basis of sustainable competitive advantage, such resources and capabilities must be valuable, rare, imperfectly imitable, and non-substitutable (Barney 1991). Firm resources and capabilities that have been examined within the resource-based view are: (a) physical resources, including the firm's physical technology, plant and equipment, geographic location, and access to raw materials and components (Barney 1991); (b) human resources, including know!edge, skills, abilities of the firm's work force; organizational resources, including routines, reporting relationships, and other integrating and differentiating mechanisms; and (c) financial resources, including the firm's credit rating, debt/equity ratio, ratio of net cash to capital expenditure, and retained earnings (Grant 1995).

Firms generally gain access to such resources through a combination of: (a) internal development and deployment (when the resources and capabilities, because of their tacit, socially complex, and specialized nature, cannot be traded in the strategic factor market; Dierickx and Cool 1989; Reed and Defillippi 1990); (b) market-based transaction (when the resources can be bought and sold in the factor market, and when a firm can purchase the resources at below-market prices relative to comperitors or when it pussesses superior knowledge/skill at evaluating the present value of future cash flows from those resources; Barney 1986); and (c) relational exchanges (when a firm possesses a particular resource or capability that generates economic rents only when it is used jointly with the resource of another firm via a joint venture or strategic alliance; Black and Boal 1994; Borys and Jemison 1989).

RBV has evolved into a distinctive body of knowledge that constitutes a "strategic theory of the firm" (Rumelt 1984). It draws on wall-established scholarly traditions in industrial organizational economics (Conner 1991), institutional (and institutionalization) theory (North 1990; Oliver 1997), and the soxiological theory of "embeddedness" (Grannoveter 1985; Uzzi 1996). Among other things, the RBV perspective "contributes to explaining firm diversicy; provides a theoretical foundacion for endogenous growth models; has all the requisite building blocks and attributes of a phylogenetic, non-consummatory, evolutionary theory; accommodates path dependencies, incorporates the predictive successes of neoclassical theory; and preserves the cumulativity of economic science" (Hunt 1997, 433).

While there is some degree of complementarity between TCE and RBV (Conner 1991; Peteraf 1993), we also note that, on an intuitive basis, a direct application of the above TCE-based logic will be difficult within the RBV framework in that 
RBV emphasizes not contracts but resources as the building blocks of the firm (Madhok 1996). Such conceptual incongruity between TCE and RBV leads to a more fundamental inquiry i.c., what theoretical explanations can the RBV offer to the issuc of firm's boundary decision in general and on entry mode choice decision in particular? Based on a survcy of RBV literature thus far, it is critically noted that, within RBV itself, research attention to the governance mode choice issue has been lacking, with rare exceptions (such as noted in Madhok 1996). While RBV, as a theory of firm, has so far provided explanations regarding the extent and direction of firm's expansion (See Penrose 1959), it has not systematically addressed the question of mode selection through which such expansions occur.

$\Lambda$ dditionally, taking an RBV perspective on mode choice has the theorctical merit of overcoming the overly static naturc of the TCE-based conceptualization that is prevalent in the current literature. Within the TCE perspective, a firm's current mode choice decision is not affected by its previous decisions, but only by a "current" set of transaction cost-sensitive variables. Thus, TCE-based perspective on mode choice is often criticized as static i.e., there is no connection between a firm's mode choices at different points of time. Furthermore, we believe such static characterization of mode choice is rather simplistic, and the RBV perspective we propose here has a conceptual merit of capturing the dynamic ${ }^{1}$ nature of mode choice behavior, an area largely ignored in the literature thus far.

To address the above theoretical deficiencies in the literature, this paper proposes an RBV perspective on governance mode choice that is based on Penrose's (1959) theoretical work. One of Penrose's major arguments is that a firm's growth is limited by the magnitude and quality of managerial resources within the firm, and che direction of the firm's growth is affected by the unused productive services and resources (including managerial ones) of the firm.

Rooted in such Penrosean conceptualization of firm growth, this paper proposes that the pattern of firm growth in general and the modes of growth in particular should also be influenced by the accumulation of managerial resources that are televant to the growth patterns and modes. Specifically, we identify a firm's stock of 'mode-sperific managerial resources' as a key determinant of the mode of governance that the firm will choose in the future. Here, we define mode-specific managerial resources as a type of specialized managerial skills and knowledge that can generate tents in a particular mode of operations, but not in other modes, even within the same firm. Therefore, in our definition, the rent generated by such mode-specific managerial resources is a type of quasi-rent or Pareto-rent (Klein, Crawford and Alchian 1978; Rumelt 1987) i.e., the difference between the value of the resource in its first best use and its value in next best use. As a real world example of such mode-specific

\footnotetext{
'Simply put, I used the word 'dynamic' for inter tcemponal connecrion between time 0 asd time 1, when the mode choice decisions are made with time interval. TCE views that there is no connection hetween the choiccs made at rime 0 and time 1 , thus a statis analysis is presumed. On the other hand, the Penrosean RBV views that the particular decision made at time 0 ( $E$.g., choice of an acyuisition) does affect the subseguent mode choice (c.g., anuthet choice of an acciuisition) through alie alcumuiation of managerial resources tailored for the mode, thus a dynamic perspecrive.
} 
managerial tesources, Polaroid hired J. Sam Ridley, a merger-and-acquisition specialist as senior vice-president in order to shift the firm's growth strategy from an incernally-based one to an acquisition-based one (Kerber 1997). In this particular case, it is expected that the managerial resource Mr. Ridley brings to Polaroid will be more useful in future 'acquisitions,' bur less useful when the firm pursues other modes of firm boundary expansion.

Specifically, the theoretical model developed in this paper has the following components. First, the amount of a firm's managerial resources developed for a particular mode should have a positive relationship with the firm's propensity to choose the mode over other alternative modes in the future. Secondly, to further explore whether such a persistent choice of modes over time by a firm is indeed influenced by the accumulation of managerial resources as predicted by the Penrosean view, or the persistence might have resulzed from 'organizational inertia' (See Hannan and Freeman 1977), where a moderated relationship by environmental uncertainty is proposed. Specifically, according to the proposed model here, it is expected that the positive linkage between mode-specific managerial resource and subsequent choice of the same mode should be stronger in contexts where uncertainty is low and weaker in contexts where uncertainty is high. An empirical rest was conducted on data pertaining to a sample of U.S. firms that engaged in foreign expansion through acquisitions and/or joint ventures.

\section{THEORETICAL BACKGROUND}

\section{Penrose's Theory of the Growth of the Firm}

Pentose (1959) conceptualized that the firm is a collection of resources, and has the motivation for growth. Such growth-motivated firms face a set of excernal productive opportunities (e.g., new technology, or a newly opened market for the existing products of the firm) which are potential areas of expansion for the firm. In this setting, Penrose addresses two basic questions: (1) to what extent will the firm pursue expansion to take advantage of those opportunities; and (2) in which direction will the furm pursue such expansion.

\section{Managerial Limit to Firm Expansion}

According to Penrose, any expansion requires managers to plan and execute tasks. Such planning and execution necessarily demands the devotion of a portion of the

\footnotetext{
Pentose's discussions span much more than these questions, including such diverse and more specific copics related to firm growth as diversification, mergers and acquisitions, the rate of growth through time, and so forth. However, for the purpose of this paper, we believe the review of her general arguments in whe cutrent form would suffice. For an extensive revicw of how Penrose's theory is related to the strategic management research, see Mahoney and Pandian (1992).
} 
current managerial services and resources available in a firm. When the amount of existing managerial resources that can be devoted to such planning and execution activitics for an expansion is insufficient, the firm faces limits to its expansion. Because the overall amount of managerial services available at a given time within the firm is constant, and also because some of the existing managerial services must be allocated to current on-going operations, there will always be a general limit on the amount of managerial services that can be devoted exclusively to such planning and execution activities.

Another aspect of managerial limits to expansion that Penrose nutes relates to the opportunity cost of allocating the services of existing mangers to the process of absorbing new managers who are hircd for expansion programs. Penrose emphasized that it is not merely the training-related costs, but also the cfficiency loss of a firm caused by the gradual nature of the absorption process ${ }^{3}$ that creates limits to expansion. New managers cannot fully provide the needed managerial services until they become effective members of the management team. To become an effective team member, one should cumulate the experiences by working together with the existing managers on a series of actual tasks over a sufficiently long period of time. 'The process is necessarily gradual because of the unicyue and scrially-embedded nature of the knowledge shared among the existing managers. Since this gradual nature of the absorption process gencrally takes up a significant amount of managerial services from existing managers at the expense of other alternative uses of the same managerial services, the firm's expansion is limited.

\section{Direction of Expansion}

Penrose viewed that the firm tends to expand in a way of utilizing more fully its unused productive services, resources, and special knowledge. Assuming the firtr's incentive to generate most profitable services out of existing resources, Penrose argued that, as long as an expansion plan can provide for a way to use the services of its resources more profitably than they are being used for current operations, the firm has an incentive to expand in such a way. Alternatively, so long as any resources are not used fully in currcnt operations, a firm will naturally have an incentive to find a way of using them more fully. According to Penrose, such unused scrvices exist in the firm for the following reasons. First of all, the unused services are created in the firm because resources are indivisible i.e., they are obtainable only in discrete amounts, and also because the firm's production function is usually subject to the balance of process where the least common multiple among the resources determines the overall output level. Secondly, the unused resources also exist due to the hetcrogencity of resources i.c., the same resources can be used differently under different circumstances. As the resources become more specialized in the firm, the more profitable uscs of the same resources are likely to be found. In addition, the unused services are gencrated

"A formal treatment of this effect of mamagerial adjustment cost on tirm growth was pursued later by Slater (1980) in the economics literature. 
from the novel combinations being created through the continuous interactions between the different types of resources in a firm.

In sum, Penrose's theory emphasizes that the stock of managerial resources available within a firm limits the firm's growth. Also, it identifies the importance of the unused resources in determining the firm's direction of expansion.

\section{Mode-specific Managerial Resources}

Many real-world examples suggest that expanding firms tend to develop their managerial resources along particular modes of expansion. Hiring of top executives who are known for their expertise in a particular mode through which a firm intends to grow is frequently reported. GTE, for instance, in its drive for revamping international operations, hired veteran international relecommunications acquisition specialist Mr. Santillana. With his expertise proven by a series of successful acquisitions he made for Spain's Telefonica SA in Latin American markets, GTE now expects him to drive the same kind of growth for the company in other foreign markets such as Canada, Asia, and Europe (Keller 1997).

The presence of mode-specific managerial resources in firms is also reflected in organizational structures. The emergence of such formal organizational arrangements as corporate level mergers-and-acquisition teams (Caves and Mchra 1986) and new business devclopment divisions indicate firms' structutal responses to the increasing organizational need to systematically develop and apply managerial skills pertaining to acq̧uisitions.

In addition, mode-specific managerial resources constitute an important source for rent-generation. In executing his growth strategy through a network of joint ventures, Mr. James Houghton, CEO of Corning, clearly realized that securing managers who can work in the unique setrings of joint venture is of crucial significance. Along this line, he observed that "to make our network come alive, people at several levels have to move across invisible borders. This requires managers with a flexible style and a broad portfolio of skills, and such individuals are normally in very short supply" (Bowet, Bartlett, Uyterhoeven and Walton 1990, 201). Accumulating such managerial resources specialized for alliances not only enabled Corning to grow further through the creation of alliance networks, but also made sure that those alliances ate managed effectively.

So far, we have argued for both the presence and importance of a firm's mode-specific managerial resources. In the following, we will explain how a firm's accumulation of mole-specific managerial resources in the past is related to its behavior of mode choice in the furure, based on Penrose's growth theory.

Firstly, the one direct implication of Penrose's theory to a firm's mode choice behavior is that when a firm possesses a greater amount of managerial resources specific to a particular mode, the firm will face a lesser degree of managerial limit in expanding through the mode. If cumulated mode-specific managerial resources are absent, the 
existing managers will have to devote a significant portion of their managerial services to digesting the particular mode of operations, in addition to the general planning required for an expansion, thus facing further managerial limit to expansion throughout the mode. Alternatively, the firm can hire new managers with skills in a particular modc. However, as clearly noted by Penrose, integrating new managers into a management team demands additional managerial services from existing managers as well, since, for any expansion, both general managetial resources and mode-specific managerial resources should necessarily be combined rather than disjoined. Parallel to the logic of Penrose, when a firm possesses a greater amount of mode-specific managerial resources, and thus, a lesser degree of managerial limit on expansion through the mode, a greater amount of expansion opportunities along the particular mode will become available to the firm. In turn, a greater feasibility set offered by the particular mode will increase the likelihood that the firm will subsequently choose one mode over other alternative modes, other factors being equal.

Secondly, Penrose emphasizes that the demand or productive opportunities for a firm are highly subjective. The amount of demand or opportunities that a firm can perceive at a given state is not fixed, rather they are varied, depending on the experience and knowledge of the firm's managers and cntreprencurs $(1959,80)$. Hence, she suggests that the relevant demand or opportunities for a firm can change qualitatively, even if there is no actual change in external environments as the firm accumulates more managerial resources through experiences.

Applying this Penrosean perspective to the mode choice issue, it is argued here that the amount of mode-specific managerial resources should have a positive effect on the likelihood of a firm's subsequent choice of the particular mode, not only because mode-specific managerial resources cnlarge the opportunity set for expansion through the mode, but also because they shape and enrich the managers' perception, or mental model, regarding the relevant opportunities based on the particular mode in a qualitative way. With the accumulation of mode-specific managerial resources, managers become more capable of identifying a larger set of the opportunities associated with the particular mode. Equivalently, even if the opportunities actually existed before, the managers could have missed them, had it not been for sufficient accumulatiun of mode-specific managerial resources. 'Io the extent that a firm's search for new productive opportunitics is driven and shaped increasingly by a particular mode for the above reason, the likelihood of the firm's choice of the mode will increase accordingly.

Finally, it is viewed that mode-specific managerial resources have a self-generating tendency i.e., new unused services are continuously created as a firm keeps applying a mode-specific managerial resource over time. According to the Pentosean perspective, this should hold even without deliberate addition of managerial resources such as hiring of trew managers, management development, and training cfforts. Penruse viewed that, while the possibilities of using services from a given resource change with changes in knowledge of the people who deal with the resource $(1959,76)$, the development of such knowledge in people is partly shaped by the resuurces they deal with, and this reciprocal relationship between resources creates the special productive 
opportunity of a particular firm (1959, 79). Hence, in this way, new opportunities can be self-generated through the interactions between existing resources of the firm, without receiving any inputs from the external environments.

Applying this view of Penrose, we view that the interactions that mode-specific managerial resource necessarily have with other resources will also continuously create such unused services, which can, in turn, generate unforeseen opportunities of expansion based on the particular mode. As a result, managers will become more and more skillful in applying their existing mode-specific resources to actual expansion programs, especially as their experiences accumulate. This is because for any expansion, the interactions of mode-specific managerial resources with the remaining other resources of the firm, including general managerial resources and physical resources are always necessary. In the context of this study's research question i.e., a firm's choice between acquisition and joint venture for its foreign market encry, the discussion so far can be summarized as follows.

Hypothesis 1. Ceteris paribus, the extent of a firm's prior experience with acquisitions will bave a pasitive effec on the likelibood of the firm's subsequent choice of an acquisition over a joint venture.

Hypothesis 2. Ceteris paribus, the extent of a firm's prior experience with joint ventures will have a positive effect on the likeliboad of the firm's subsequent choice of a joint venture over an arquisition.

In Hypotheses 1 and 2, for the purpose of operationalizing the above theoretical argument into an empirically testable form, the extent of a firm's prior experience in a mode is taken as a proxy for the firm's cumulated amount of managerial resource specific to the mode. The rationale is that mode-specific managerial resources are characterized in this study as unique firm-specific knowledge assets, and learningby-doing should be an important way of increasing the stock of such knowledge (Polanyi 1962).

\section{Uncertainty and Mode-specific Managerial Resources}

At the empirical level, Hypotheses 1 and 2 basically predict a persistent pattern of a firm's mode choice over time. However, it is critically recognized that the same prediction can be made, not only from the Penrosean perspective, but also from the perspective of organizational inertia. The firm may be deterred from shifting to orher modes, largely because of such inertial forces as sunk cost arising from dedicated investment in specialized resources and structure for the mode, information constraints, internal political constraints, or cumulated organizational history (Hannan and Freeman 1977).

Given the presence of such a competing perspective, for the purpose of falsification, it seems necessary to observe the pattern of moderation by environmental uncertainty on the hypothesized relationships above. Specifically, from the inertia perspective, 
it is expected that the positive experience-choice linkage should be stronger in high uncertainty contexts than in low uncertainty contexts. High environmental uncertainty will increase, rather than decrease, inertial pressure, and the increased inertial pressure will, in turn, strengthen the positive expcrience-choice linkage. First, as uncertainty increases, while acquiring external information becomes more important, it also becomes more costly in general. In addition, the internal organizarional process of acquiring information becomes increasingly less efficient because the type of specialists employed by the organization constrains both the nature of information it is likely to obtain and the kind of specialized information it can process and utilize (Flannan and Freeman 1977). And this overall lower efficiency in acquiring information nceded for a firm's structural adaptation i.e., a shift from one mode to another in high uncertainty environuments, will provide a stronger inertial pressure by raising the cost of shifting higher. And it is self-evident that the stronger inertial pressure in higher uncertainty environments will strengthen the likelihood that the firm will choose the same mode it chose in the past.

In contrast, in the Penrosean perspective, an opposite pattern is expected i.e., the positive experience-choice linkage should be weaker in high uncertainty contexts than in low uncertainty contexts. High environmental uncertainty will decrease the amount of mode-specific managerial services that can be devoted to expansion, and the reduced mode-specific managerial services will, in turn, weaken the positive experience-choice linkage. Similar to the inertia model, Penrose also views that uncertainty has an effect of increasing the amount of information that need to be acquired by the firm. However, in Penrose's framework, the effect of such need for information acquisition is conceptualized differently i.e., as increasing the amount of managerial services required for expansion. Thus, "for any given amount of expericnced managerial scrvices, risk and uncertainty will effectively limit expansion" $(1959,64)$. Accordingly, our Penrosean moxtel of mode choice would also prescribe that a greater amount of managerial service tequired for expansion through a parcicular mode in high uncertainty contexts will limit the expansion through a particular mode to a greater extent, compared to low uncertainty contexts. Thus, contrary to the prediction of the incrtia model, uncertainty in our model will weaken the likelihood that the firm will choose the same mode it chose in the past.

The discussion so far is summarized in the following hypotheses. Building on the foreign entry mode literature (Stopford and Wells 1972; Kogut and Singh 1986; Caves and Mehra 1986; Gatignon and Anderson 1988; Gomes-Casseres 1989; Hennart 1991), we identify three categories of environmental uncertainty in the context of U.S. firm's foreign expansion: (1) L.S. Firm's prior experience in host country; (2) culture distance of host country from the U.S.; and (3) product diversification represented by foreign expansion from the existing lines of business of the U.S. firm.

Hypothesis 3. The positive effect of a firm's prior experience in a particular mode on the likelibood of the firm's iubstquent choice of the same mode over atber alternative modes will be stronger when the firm's sperational experience 
in the bost country is high than when it is low.

Hypothesis 4. The positive effect of a firm's prior experience in a particular mode on the likelibood of the firm's subsequent choice of the same mode over atber alternative modes will be stronger when the culture distance of a bost country from the U.S. is low than when it is bigh.

Hypothesis 5. The positive effect of a fim's prior experience in a particular mode on the likelibood of the firm's subsequent choice of the same made over other alternative modes will be stronger when foreign expansion is along the firm's existing lines of business than when it also represents product diversification.

\section{METHODS}

\section{Sample}

We collected data on U.S. firms' foreign expansion through acquisitions and/or joint ventures during the period of 1986-1990 from various publicly available sources including the Wall Street Joumal Index, Predicast Funk and Scott Index of Corporate Policy Changes, Yearbook on Conporate Mergers, Acquisitions, and Joint Ventures, and Mergers and Acquisitions. For data compatibility, we chose to focus only on the manufacturing sector (i.e., SIC 2000-3999), since systematic differences were reported in the pattern of mode choice betwcen manufacturing and service sectors (See Kogut and Singh 1988). For the foreign countries involved, we restricted our sampling within capitalistic economies for the purpose of controlling potential exogenous effects due to the differences in economic systems. While we included the countries with restrictive government policies on foreign ownership in our sample, in our tests, we controlled this policy effect by entering a dummy variable.

The final data set we used for statistical analyses consisted of 129 acquisitions and IVO joint ventures, after excluding observations with missing data. In our data set, a total of 67 U.S. firms were represented, with firm size ranging from $\$ 38$ million to $\$ 12$ billion in net sales. The data set also included 33 foreign countries entered by U.S. firms, with the highest concentration in such developed countries as the U.K., France, Germany, and Japan, followed by a group of newly industrializing countries such as Brazil and Mexico. Foreign expansion activities were reported in almost all manufacturing segments, with higher frequencies in chemicals and allied products, motor vehicles and equipment, food, and electrical equipment.

\section{Measures}

\section{Dependent Variable}

We define the dependent variable as the likelihood of a firm's choice of an acquisition 
over a joint venture (acquisition takes the value of 1 , joint venture 0 ). We operationalize acquisitions and joint ventures in the following ways. Following Kogut and Singh (1988), we vicw an acquisition as "the purchase of stock in an already existing company in an amount sufficient co confer control" (412). While we used this definition as a general rule in identifying and categorizing acquisitions in the data collection procedure, in some cases where the information on the controlling equity was not directly available, we used variations of the following expressions in related articles as proxies: (1) U.S. firm $A$ acquired foreign firm B; (2) U.S. firm A purchased a majority stake of foreign firm B; or (3) U.S. firm A acquired more than $50 \%$ of the stocks of foreign firm B. On the other hand, we excluded the cases of less than $50 \%$ equity purchases with unknown controlling position by U.S. firms from the acquisition category. We also excluded cases of minority equity investment, since they represcnt a qualitatively different mechanism from both acquisitions and joint ventures (Kogut and Singh 1988).

Following Kogut and Singh (1988), we adopted the joint venture definition of "the pooling of assets in a common and separate organization by two or more firms who share joint ownership and control over the use and fruits of these assets." Thus, we used "the existence of the two parent firms as separate entities after venture formation" as an important defining characteristic in identifying joint ventures. We note that the existing research sometimes used a broader definition of joint ventures as partial ownership and control as well (See Gatignon and Anderson 1988; CromesCasseres 1989; Hennart 1991). However, we chose this third-party definition on the hasis that it fits conceptually better within our study i.e., joint ventures are viewed in our study as a unique mode of expansion that require qualitatively different managerial skills from those for the acquisition mode, rather than the relative amount of control per se.

\section{Firm's Prior Mode Experience}

We operationalized the extent of a U.S. firm's prior experience in a particular mode by the frequency of the firm's choice of the mode during the 1981-1985 period i.e., the last 5 years prior to our study period (1986-1990). Specifically, the "firm's prior experience with acquisitions" (ACQEXP) was operationalized by the number of both domestic and international acquisitions made by the U.S. firm during the 1981-1985 period. Similarly, the "firm's prior experience with joint ventures" (JVEXP) was measured by the number of both domestic and international joint ventures formed by the focal firm during the $1981-85$ period. For data sources, we used Mengers and Acquisitions, and Predicast Funk and Sott Index of Corporate Policy Changes.

\section{Uncertainty}

The three categories of operational uncertainty are operationalized in the following 
ways. For a firm's prior country experience, we constructed a scale variable, "lack of country experience" (LACKCEXP) taking '2' if a focal U.S. firm has no prior operations in the host country at the time of entry, ' $\mathrm{I}$ ' if the firm has at least one non-manufacturing (e.g., salcs) operations but no manufacturing operations, and $'{ }^{\prime}{ }^{\prime}$ if the firm has at least one manufacturing operations. We made an assumption here that manufacturing activities in a foreign country should involve more diverse and complex operations, thus creating a higher uncertainty than within nonmanufacturing activities. In support of this view, Johanson and Vahlne (1977) and Root (1987) observe that non-manufacturing subsidiaries (e.g., sales and service) tend to precede manufacturing subsidiaries in the sequential process of firms' internationalization. We used the Insernational Directory of Conponate Affiliations as the data source for LACKCEXP.

"Culture distance between home and host countries" (CULTDIST) also creates operational uncertaincy (Kogut and Singh 1988; Barkema, Bell and Pennings 1996). For operationalization, we adopted the culture distance index originally constructed by Kogut and Singh (1988), based on Hofstede's cultural dimensions (1980, 1991). We note that several other studies also used the Kogut and Singh's culture distance measure (See Agarwal and Ramaswami 1992; Benito and Gripsrud 1992; Cho and Padmanabhan 1992; Barkema, Bcll and Pennings 1996). A formal definition of CLLTDIST is stated as follows.

$$
\text { CULTDISTi }=\sum_{j, j}^{4} \sqrt{(S i j-S u S j)^{2} / \operatorname{Var}(j)}
$$

where,

$S_{i j}=$ culture score of a foreign country $i$ on cultural dimension $j$

Susj $=$ culture score of the U.S. on cultural dimension $j$

$\operatorname{Var}(j)=$ variance of scores among the countries studied in Hofstede (1991) on cultural dimension $j$

Cultural dimensions: $j=1$ for power distance, 2 for individualism, 3 for masculinity, and 4 for uncertainty avoidance

We expect that operational uncertainty involved in diversifying expansion should be higher than in non-diversifying expansion. We constructed "product diversification" (PRODDIVN), as a binary variable taking ' 1 ' if the product area of foreign expansion does not match, at 4-digit SIC levcl, with the U.S. firm's primary business segment as reported in SEC 10-K filing, and ' 0 ' if there is such a match. A firm's 4-digit primary business segment reported in $10-K$ filing was previously used as the basis of measuring diversification in strategy research (See Koh and Venkatraman 1991). We gathered the data on U.S. firms' primary business segments from the COMPUSTAT database. We determined the 4-digit SIC definition of the product area of foreign expansion by content analyses of related articles, and in limited cases, by the SIC 
definition reported later by the firm in the International Directory of Corporate Affiliations. An independent crosscheck by a doctoral student majoring in strategy confirmed the replicability of the content analysis method.

\section{Control Variables}

Based on the foreign entry mode literature (Kogut and Singh 1986; Caves and Mehra 1986; Gatignon and Anderson 1988; Gomes-Casseres 1989; Hennart 1991), we include the following control variables in our tests.

When a host government imposes a policy of that either restricts foreign ownership or encourages joint venture with local partners, the actual mode chosen by a firm does not necessarily reflect the firm's frrst best choice. Both Gatignon and Anderson (1988) and Gomes-Casseres (1989) found such restrictive host government policy as a significant factor determining firms' actual choice of a mode. Therefore, in this study, we included a control variable for "host government restriction" (GOVERESTR) in the model tests. GOVERESTR is a binary variable taking ' 1 ' if a host government has a restrictive policy, and ' 0 ' if not. Based on the data by the Department of Commerce used in Gomes-Casseres (1989), we considered Australia, Brazil, Columbia, Ecuador, France, India, Indonesia, Iran, Japan, Korea, Malaysia, Mexico, New Zealand, Nigeria, Pakistan, Peru, Philippines, Spain, Sri Lanka, and Venezuela as restrictive host governments.

The likelihood of a joint venture over a wholly-owned subsidiary was found to be significantly high in natural resource-based industries (e.g., food, tobacco, pulp, ctc.) (Gomes-Casseres 1989; Hennart 1991). Compared to forcign firms, local firms may have privileged access to a domestic supply of such natural rcsources, and the domestic market for these resources is usually not competitive. Hence, foreign firms may find joint ventures with local partners more attractive than wholly-owned subsidiaries in this type of industries. To control for such industry effect, we included a dummy variable "natural resource" (RESOURCE) taking ' 1 ' if the industry of an expansion is natural resource-based, and ' 0 ' if not. Following Comes-Casseres (1989), we included food and beverage (SIC 20), tobacco (SIC 21), textile mills (SIC 22), wood except furniture (SIC 24), pulp and paper (SIC 26), petroleum (SIC 29), rubber (SIC 30), and primary metals (SIC 33) as natural resource-based industries.

Firm size is another variable that has been frequently included in mode choice research (Dubin 1975; Wilson 1980; Caves and Mehra 1986; Kogut and Singh 1988; Hennart 1991). Kogut and Singh (1988) note that acquisitions tend to require more financial and managerial resources than joint ventures, therefore, smaller firms, due to resource constraints, may inherently be less likely to choose acquisitions over joint ventures. To control for such effect, we included "firm size" (SALES) i.e., the U.S. firm's net sales (\$) in the year of expansion. We used the COMPUSTAT database for net sales data.

The TCE-based mode choice literature underscores intangible assets such as 
technological know-hows, brand reputation, and other firm-specific proprietary knowledge as a key determinant of mode choice, because these assets are highly susceptible to transaction hazards by nature (Gatignon and Anderson 1988; Gomes-Casseres 1989; Hennart 1991). Accordingly, in this study, we included firm-level technological intensity (RNDINT) and advertising intensity (ADVINT) as control variables. RNDINT is operationalized by the ratio of R\&D expenses to net sales of the U.S. firm in the year of expansion. Similarly, ADVINT is operationalized by the ratio of advertising expenses to net sales of the U.S. firm in the year of expansion. Both types of expense data were collected from the COMPUSTAT database. Descriptive statistics for all the variables discussed so far are summarized in Table 1.

Table 1. Means, Standakd Deviations, and Corrflations ${ }^{2}$

\begin{tabular}{|c|c|c|c|c|c|c|}
\hline Variables & Means & s.d. & 1 & 2 & 3 & 4 \\
\hline 1. Host government restriction & .38 & .49 & 1.00 & & & \\
\hline 2. Natural resource industry & .29 & .46 & -.08 & 1.00 & & \\
\hline 3. Firm size & 19111.50 & 30403.65 & .07 & $-.24^{*}$ & 1.00 & \\
\hline 4. Firm R\&D intensity & 3.46 & 2.77 & .05 & $-.48^{*}$ & .03 & 1.00 \\
\hline 5. Firm advertising intensity & 4.83 & 5.02 & .06 & $.17^{\circ}$ & $-.23^{\circ}$ & -.01 \\
\hline 6. Lack of country experience & 1.66 & .88 & .07 & -.07 & .05 & -.04 \\
\hline 7. Culture distance & 1.37 & 1.11 & $.47^{\circ}$ & $-.14^{*}$ & $.16^{\circ}$ & .07 \\
\hline 8. Proxluct diversification & .34 & .47 & .10 & $-.12^{*}$ & $-.11^{\prime}$ & $.17^{\circ}$ \\
\hline 9. Acquisition experience & 4.83 & 5.04 & $.16^{\circ}$ & -.03 & $.16^{\circ}$ & -.07 \\
\hline 10. Joint venture experience & 4.17 & 5.02 & $.16^{\circ}$ & $-.33^{\circ}$ & $.55^{\circ}$ & $.24^{\circ}$ \\
\hline Variables & 5 & 6 & 7 & 8 & 9 & 10 \\
\hline \multicolumn{7}{|l|}{ 1. Host government restriction } \\
\hline \multicolumn{7}{|l|}{ 2. Natural resource industry } \\
\hline \multicolumn{7}{|l|}{ 3. Firm size } \\
\hline \multicolumn{7}{|l|}{ 4. Firm R\&D intensiry } \\
\hline 5. Firm advertising intensity & 1.00 & & & & & \\
\hline 6. Lack of country experience & $-.11^{\circ}$ & 1.00 & & & & \\
\hline 7. Culture distance & -.05 & $.29^{\circ}$ & 1.00 & & & \\
\hline 8. Product diversification & $-.14^{*}$ & $-.14^{\prime \prime}$ & .03 & 1.00 & & \\
\hline 9. Acquisition experience & $-.18^{4}$ & -.08 & $.13^{\circ}$ & $27^{\circ}$ & 1.00 & \\
\hline 10. Joint venture experience & $.27^{*}$ & -.05 & $.18^{\circ}$ & .12 & $46^{\circ}$ & 1.00 \\
\hline
\end{tabular}

Note: a: $\mathrm{N}$ is 229 for all the variables except for "Ratio of acquisition over joint venture" for which $\mathrm{N}$ is 210 . Two-tailed Pearsen correlarion cixfficients are repured.

$* p<.05$ 


\section{RESULTS}

Due to the binary nature of the dependent variable in this study, we adopted logistic regression analysis as the statistical method for testing the hypotheses. In Table 2, the results of the logistic regression analyses are reported. Equation I (baseline model) tests the effect of variables that are known to be significant in earlicr studics. Government restriction (GOVERESTR) showed a significant negative coefficient, confirming that restrictive host country policies create an institutional force to support joint ventures over acquisitions by foreign firms. Resources industry (RESOURCE) was not a significant variable in explaining a firm's mode choice berween joint ventures and acçuisitions. SALES, measuring the size of parent company, showed a significantly negative sign i.e., increasing the possibility of choosing joint ventures over acquisitions. While advertising intensity (ADVINT) increased the likelihood of choosing acquisitions over joint ventures, R\&D intensity (RNDINT) showed an opposite effect i.e., promoting the choice of joint ventures. Lack of country experience (LACKCEXP) and cultural distance between the U.S. and host country (CULTDIST) showed significant effects of increasing the possibility of joint ventures over acquisitions.

\section{Hypothesis 1: The effect of prior acquisition experience}

Table 2 summarizes the test results on Hypothesis 1 , which predicted a positive effect of a firm's prior experience with acquisitions (ACQEXP) on its subsequent choice of an acquisition over a joint venture. In equation II, contradictory to our prediction, the effect of ACQEXP was not significant at $p<.10$ level.

\section{Hypothesis 2: The effect of prior joint venture experience}

Equations III in Table 2 reports the result on the effect of firm's prior experience with joint ventures (JVEXP). Supporting our hypothesis, JVEXP significantly increased the likelihood of a firm's subsecquent choice of a joint venture over an acquisition $(p<.01)^{4}$

We also tested for how model performance improved by the inclusion of JVEXP against the base-line model containing only the control variables (equation $I$ in Table 2). Entering JVEXP significantly improved the model's power, as indicated by statistically significant increases in $\chi^{2}$ values $(p<.01)$. Another measure of how well our model explains the empirical regularities in the data set is the classification percentage, and our models showed satisfactory rcsults in this regard as well. As reported in Table

\footnotetext{
'Since there is a high corretation between joint venture experience (JVEXP) and firm sizc (SALES), I conducted a separate test to see if multi-collinearicy problem exists. The rest showed no substantial rhange in the significance of JVEXP after controlling the effect of SALES. 1 am grateful to one the reviewers for suggesting this rest.
} 
3, for instance, the classification percentage of $77.29 \%$ in equation IIJ of Table 2 was satisfactory on the basis that it is much higher than the classification percentage calculated based on pure chance with relatively controlled catcgory size (i.e., 50.79\% in our sample). 5

TABLE 2. RESULTS OF LOGISTIC REgRESSION ANALYSIS

(DEPENDENT Varlable = PROBabILITY OF ChOOSING ACQLiSITION OVER Joint Ventire; Beta Coefficients with Standaro ekrors in Parentheses)

\begin{tabular}{|c|c|c|c|}
\hline Indepencient Variables & Baseline Model & $\stackrel{\text { U }}{\text { Entering } A C Q E X P}$ & $\begin{array}{c}\text { III } \\
\text { Entering JVEXP }\end{array}$ \\
\hline GOVERESTR & $\begin{array}{l}-1.06 \\
(.37)^{* 4 *}\end{array}$ & $\begin{array}{l}-1.03 \\
(.37)^{* *+7}\end{array}$ & $\begin{array}{c}-.97 \\
(.38)^{* *}\end{array}$ \\
\hline RESOURCE & $\begin{array}{l}-.27 \\
(.43)\end{array}$ & $\begin{array}{r}-.28 \\
(.43)\end{array}$ & $\begin{array}{l}.39 \\
(.44)\end{array}$ \\
\hline SALES & $\begin{array}{l}-1.9 \mathrm{E}-05 \\
(6.3 \mathrm{E}-06)^{* * *}\end{array}$ & $\begin{array}{l}-1.8 \mathbf{8 E} \cdot 05 \\
(6.2 \mathrm{E}-06) * *\end{array}$ & $\begin{array}{r}-6.9 \mathrm{E}-06 \\
(7.2 \mathrm{E}-06)\end{array}$ \\
\hline RNDINT & $\begin{array}{l}-.20 \\
(.06)^{-*}\end{array}$ & $\frac{-.21}{(.07)^{* * *}}$ & $(.07)^{-.17}$ \\
\hline ADVINT & $(.03)^{\circ *}$ & $(.07)^{* *}$ & .05 \\
\hline LACKCEXP & $(.67)^{.0 *}$ & $(.20)^{-. * *}$ & $(.20)^{6 * *}$ \\
\hline CULTDIST & $\begin{array}{c}-.52 \\
(.17)^{* * 4}\end{array}$ & $(.17)^{-.54}$ & $(.17)^{-.5 *}$ \\
\hline PRODDIVN & $\begin{array}{l}.30 \\
(.37)\end{array}$ & $\begin{array}{l}.39 \\
(.28)\end{array}$ & .53 \\
\hline ACQEXP & & $\begin{array}{l}-.03 \\
(.03)\end{array}$ & \\
\hline JVEXP & & & $(.04)^{-.15}$ \\
\hline Constant & $\begin{array}{c}3.25 \\
(.65)^{\circ}\end{array}$ & $(.69)^{3.43}$ & $\begin{array}{l}3.72 \\
(.69)^{4+4}\end{array}$ \\
\hline -2 Log Likelihood & 226.30 & 225.45 & 214.42 \\
\hline Model $\chi^{2}$ (d.f.) & $87.48^{407}(8)$ & $88.32^{* * *}(9)$ & $99.35^{\circ 40}$ (9) \\
\hline$\Delta \chi^{2}$ (d,f.) from $\mathrm{Eq}, \mathrm{I}$ & - & $.84(1)$ & $11.87^{* * 2}(1)$ \\
\hline Correct $\%$ & $75.55 \%$ & $76.42 \%$ & $77.29 \%$ \\
\hline$N$ & 229 & 229 & 229 \\
\hline
\end{tabular}

Note: Tests of significance (one-tail): $* p<.10, * * p<.05, * * p<.01$

We used a method suggested by Morrison (1976) where the criterion percentage is calculated from $p^{2}$ $+(1-p)^{2}$, and $p$ is the proportion of the smaller caregory i.e., joint venture in our sample. 
Table 3. Classification Table (Equation ili in Table 2)

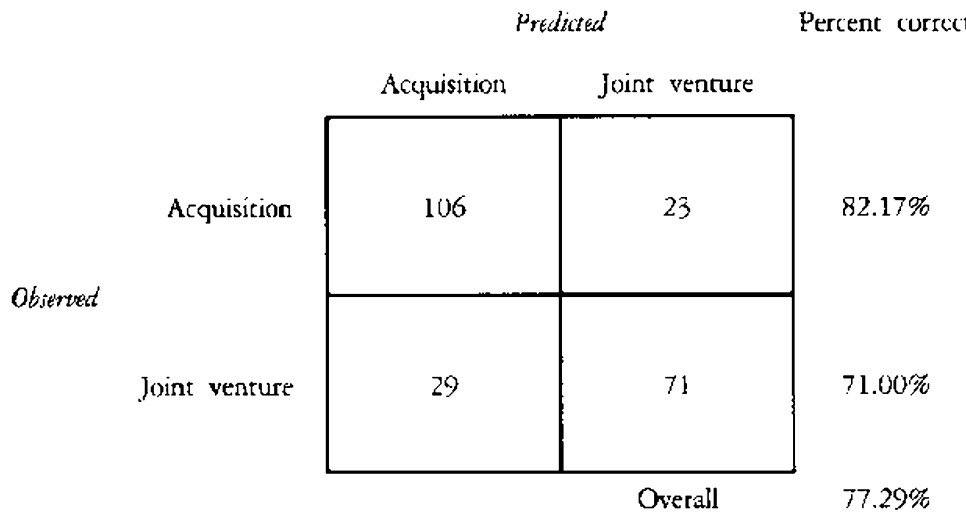

\section{Hypothesis 3: Moderation effect by country experience}

Hypothesis 3, 4, and 5 state that the positive effect postulated in Hypotheses 1 and 2 (i.e., a firm's prior experience in a mode should increase the probability that the firm will subsequently choose the same mode) should be stronger in low uncertainty contexts, and less strong in high uncertainty contexts. We chose to conduct subgroup analyses for testing the hypothesized moderation relationships. It has been supported in the strategy literature that the method of using subgroup analysis, compared to an alternative method of entcring an interactive term (i.e., created by multiplication of two or more variables) into a model, fits better with research designs where the nature of proposed moderation relationships is one of strength rather than of form (Venkatraman 1989, 426). As stated in Hypotheses 3, 4 and 5, the strength of moderation is of interest in our study.

Among the three categories of environmental uncertainty examined in our study, Table 4 first summarizes the results on the moderated cffect by a firm's "lack of country experience" (LACKCEXP). We split the sample into two subgroups based on the value of LACKCEXP; a particular expansion was assigned to the "low country experience" subgroup (i.e., high uncertainty) if its LACKCEXP value is 2 (= no prior subsidiary operation in the host countryl, and to the "high country experience" subgroup (i.e., low uncertainty) if its LACKCEXP value is either 0 or 1 (= any type of prior subsidiary operations).

We found that the effects of ACQEXP were not significant in either low or high country experience subgroup at $p<.10$ level (equations I and II of Table 4), thus, Hypothesis 3 was not supported.

On the other hand, Hypothesis 3 was supported in the cases of joint ventures, i.c., while JVEXP increased the odds that the firm will subsequently choose a joint venture over an acquisition in both high and low country experience subgroups. The 
effect was stronger in high country experience subgroup ( $=$ low uncertainty) than in low country experience subgroup $(=$ high uncertainty) $(\phi<.01$ versus $p<.10$ ). The method of comparing coefficient significance levels between different subgroups has been used in the strategy literature (See Barkema, Bell and Pennings 1996).

Table 4. Results of Logistic Regression ANALysis: MOdRRation EFfects BY COUNTRY EXPERUENCE (DEPENDENT VARIABLE = Probability of ChOOSING ACQUisition OVER JOINT Venture; Beta COEFFICIENTS WITH STANDARD ERrors IN PARENTHesbs)

\begin{tabular}{|c|c|c|c|c|}
\hline $\begin{array}{l}\text { Independent } \\
\text { Variables }\end{array}$ & $\begin{array}{c}\text { I } \\
\text { Low } \\
\text { Country } \\
\text { Experience } \\
\text { Group }\end{array}$ & $\begin{array}{c}\text { II } \\
\text { High } \\
\text { Country } \\
\text { Expurience } \\
\text { Group }\end{array}$ & $\begin{array}{c}\text { III } \\
\text { Low } \\
\text { Country } \\
\text { Experience } \\
\text { Group }\end{array}$ & $\begin{array}{c}\text { IV } \\
\text { High } \\
\text { Country } \\
\text { Experience } \\
\text { Group }\end{array}$ \\
\hline GOVERESTR & $\begin{array}{c}-3.40 \\
(1.31)^{\circ \cdots}\end{array}$ & $\begin{array}{c}-.67 \\
\{.45)^{\circ}\end{array}$ & $\begin{array}{c}-3.28 \\
(1.24)^{* * *}\end{array}$ & $\begin{array}{l}-.61 \\
(.45)^{*}\end{array}$ \\
\hline RESOURCE & $\begin{array}{l}-1.48 \\
(.98)^{* *}\end{array}$ & $\begin{array}{l}.35 \\
(.56)\end{array}$ & $\begin{array}{l}-1.07 \\
(.91)\end{array}$ & $\begin{array}{l}.29 \\
(.56)\end{array}$ \\
\hline SALES & $\begin{array}{c}-.01 \\
(7.6 E-05)^{\circ}\end{array}$ & $\begin{array}{l}-1.7 E-05 \\
(6.3 E-06)^{\circ * *}\end{array}$ & $\begin{array}{l}-8.2 \mathrm{E}-05 \\
(7.2 \mathrm{E}-05)\end{array}$ & $\begin{array}{l}-8.0 \mathrm{E}-06 \\
(7.4 \mathrm{E}-06)\end{array}$ \\
\hline RNDINT & $\begin{array}{c}-.29 \\
(.20)^{*}\end{array}$ & $\begin{array}{c}-.19 \\
(.07)^{* * *}\end{array}$ & $\begin{array}{l}-.17 \\
(.17)\end{array}$ & $\begin{array}{c}. .15 \\
(.07)^{-*}\end{array}$ \\
\hline ADYINT & $\begin{array}{c}.31 \\
(.12)^{* * *}\end{array}$ & $\begin{array}{l}.03 \\
(.04)\end{array}$ & $\begin{array}{l}.26 \\
(.10)^{\circ "}\end{array}$ & $\begin{array}{l}.01 \\
(.04)\end{array}$ \\
\hline CULTUIST & $\begin{array}{l}-.36 \\
(.42)\end{array}$ & $\begin{array}{c}-.54 \\
(.20)^{* * *}\end{array}$ & $\begin{array}{l}-.43 \\
(.45)\end{array}$ & $\begin{array}{c}-.53 \\
(.20)^{* .10}\end{array}$ \\
\hline PRODDIVN & $\begin{array}{c}2.53 \\
(1.27)^{* *}\end{array}$ & $\begin{array}{l}-.01 \\
(.45)\end{array}$ & $\begin{array}{c}2.48 \\
(1.28)^{\circ *}\end{array}$ & $\begin{array}{l}.10 \\
(.44)\end{array}$ \\
\hline ACQEXP & $\begin{array}{l}.25 \\
(.20)\end{array}$ & $\begin{array}{l}-.03 \\
(.04)\end{array}$ & & \\
\hline JVEXP & & & $\begin{array}{l}-.18 \\
(.21)\end{array}$ & $\begin{array}{c}-.13 \\
(.05)^{* * *}\end{array}$ \\
\hline Constant & $\begin{array}{c}.87 \\
(1.03)\end{array}$ & $\begin{array}{l}2.64 \\
(.65)^{2 .}\end{array}$ & $\begin{array}{c}1.36 \\
(1.07)^{*}\end{array}$ & $(.63)^{2.8 *}$ \\
\hline-2 Log Likelihond & 41.02 & 164.39 & 41.59 & 157.64 \\
\hline Model $z^{2}$ (d.f.) & $40.188^{40 *}(8)$ & $51.65^{k+4}(8)$ & $39.91^{* * 4}(8)$ & $58.40^{* * 0}(8)$ \\
\hline Correct $\%$ & $85.71 \%$ & $77.11 \%$ & $80.95 \%$ & $78.92 \%$ \\
\hline $\mathrm{N}$ & 63 & 166 & 63 & 166 \\
\hline
\end{tabular}

Note: 'Tests of significance (one-tail): *p<.10,**p<.05,***p<.01

Hypothesis 4: Moderation effect by culture distance

Table 5 summarizes the test results regarding the moderated relationships by culture distance (CULTDIST) on the effect of a firm's prior mode expetiences on its subsequent 
choice of the same mode. For sample split, since thete was no relevant a priori cut off point available for this variable, we adopted the sample median value of CULIDIST (1.55) as the basis of constructing subgroups.

Hypothesis 4 was not supported when we compared the effects of ACQEXP in high versus low culture distance subgroups (equations I and II of Table 5), The coefficients of ACQEXP were negative and not significant at $p<.10$ level in both subgroups.

To the contrary, in joint ventures, we found support for Hypothesis 4 i.e., in equations III and IV, JVEXP's significance level was higher in the "low" culture distance subgroup (= low uncertainty) than in the "high" culture distance subgroup (= high uncertainty) $(\phi<.01$ and $p<.10$, respectively).

TABIE 5. RESIJITS OF IOGISTIC REgRESSION ANALYSIS: MODERATION EFFECTS BY CUL'TURE DISTANCE (DEPENDENT VARIABLE = PROBABILITY OF CHOOSING ACQUISI'IION OVER JOINT VENTI!RE; BETA COEFFICIEN'IS WITH STANDARD ERRORS IN PARENTHESES)

\begin{tabular}{|c|c|c|c|c|}
\hline $\begin{array}{l}\text { Independent } \\
\text { Variables }\end{array}$ & $\begin{array}{c}1 \\
\text { High } \\
\text { Culture } \\
\text { Distance Group }\end{array}$ & $\begin{array}{c}\text { II } \\
\text { Low } \\
\text { Culture Distance } \\
\text { Group } \\
\end{array}$ & $\begin{array}{c}\text { III } \\
\text { High } \\
\text { Culture } \\
\text { Distance Group }\end{array}$ & $\begin{array}{c}\text { JV } \\
\text { Low } \\
\text { Culture Distance } \\
\text { Group }\end{array}$ \\
\hline GOVERESTR & $\begin{array}{l}-.36 \\
(.49)\end{array}$ & $\begin{array}{l}-3.29 \\
(.93)^{\ldots *}\end{array}$ & $\begin{array}{l}-.32 \\
(.49)\end{array}$ & $\begin{array}{c}-3.41 \\
(1.00)^{* * *}\end{array}$ \\
\hline KESOL'RCE & $\begin{array}{l}.10 \\
(.56)\end{array}$ & $\begin{array}{l}-.49 \\
(.75)\end{array}$ & $\begin{array}{l}.05 \\
(.56)\end{array}$ & $\begin{array}{l}-.73 \\
(.77)\end{array}$ \\
\hline SALES & $\begin{array}{c}-2.0 \mathrm{E}-05 \\
(8.7 \mathrm{E}-06)^{\circ * *}\end{array}$ & $\begin{array}{c}-1.9 \mathrm{E}-05 \\
(9.0 \mathrm{E}-06)^{*}\end{array}$ & $\begin{array}{l}-1.2 \mathrm{E}-05 \\
(1.0 \mathrm{E}-05)\end{array}$ & $\begin{array}{l}-9.1 \mathrm{E}-06 \\
(1.0 \mathrm{E}-05)\end{array}$ \\
\hline KNDINT & $(.09)^{* * * *}$ & $\begin{array}{l}-.25 \\
(.10)^{*+1}\end{array}$ & $\begin{array}{c}-.20 \\
(.09)^{* *}\end{array}$ & $\begin{array}{l}-.21 \\
(.11)^{* *}\end{array}$ \\
\hline ADVINT & $\begin{array}{l}.04 \\
(.04)\end{array}$ & .08 & $\begin{array}{l}.03 \\
(.04)\end{array}$ & $\begin{array}{l}.06 \\
(.06)\end{array}$ \\
\hline LACKCEXP & $\begin{array}{c}. .81 \\
(.27)^{* \cdots}\end{array}$ & $\frac{-.95}{(.33)^{* * *}}$ & $\begin{array}{l}-.84 \\
(.27)^{n+*}\end{array}$ & $\begin{array}{l}.94 \\
(.35)^{* * *}\end{array}$ \\
\hline PRODDIVN & $\begin{array}{l}-.27 \\
(.52)\end{array}$ & $\begin{array}{r}.84 \\
(.62)^{\circ}\end{array}$ & $\begin{array}{l}-.18 \\
(.52)\end{array}$ & $.91)^{\circ}$ \\
\hline$A C Q E X P$ & $\begin{array}{l}-.04 \\
(.04)\end{array}$ & $\begin{array}{l}-.05 \\
(.06)\end{array}$ & & \\
\hline JVEXP & & & $\begin{array}{l}. .09 \\
(.06)^{*}\end{array}$ & $\begin{array}{l}-20 \\
(.06)^{\circ}\end{array}$ \\
\hline Constant & $\begin{array}{l}2.77 \\
(.98)^{* * *}\end{array}$ & $\begin{array}{c}3.64 \\
(1.10)^{* * *}\end{array}$ & $\begin{array}{l}2.73 \\
(.95)^{* * *}\end{array}$ & ${ }^{4.19}$ \\
\hline -2 Log Likelihood & 126.01 & 95.17 & 124.15 & 85.15 \\
\hline Model $\chi^{2}$ (d.f.) & $31.99^{4 * *}(8)$ & $41.32^{* * *}$ & $33.85^{* * *}(8)$ & $51.33^{* * *}(8)$ \\
\hline Correct $\%$ & $71.55 \%$ & $84.07 \%$ & $74.14 \%$ & $85.84 \%$ \\
\hline$N$ & 116 & 113 & 116 & 113 \\
\hline
\end{tabular}

Note: Tests of significance (one-tail): ${ }^{*} \mathrm{p}<.10,{ }^{* *} \mathrm{p}<.05,{ }^{* * *} \mathrm{p}<.01$ 
Hypothesis 5: Moderation effect by product diversification

TABIE 6. RESLITS OF LOGISTIC REgRession ANAI.YSIS: MODERATION EFPECTS BY PRODUCT DIVERSIFICATION (DEPENDENT VARIABLE =Probability of Choosing acquisition OVer JoINT Ventlik;

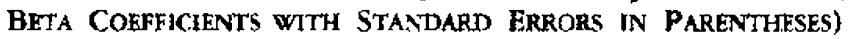

\begin{tabular}{|c|c|c|c|c|}
\hline $\begin{array}{l}\text { Independent } \\
\text { Variables }\end{array}$ & $\begin{array}{c}\text { I } \\
\text { High Product } \\
\text { Diversification } \\
\text { Group }\end{array}$ & $\begin{array}{c}\text { II } \\
\text { Low Product } \\
\text { Diversification } \\
\text { Group }\end{array}$ & $\begin{array}{c}\text { III } \\
\text { High Product } \\
\text { Diversification } \\
\text { Group }\end{array}$ & $\begin{array}{c}\text { IV } \\
\text { Low Product } \\
\text { Diversificarion } \\
\text { Group } \\
\end{array}$ \\
\hline GOVERESTR & $\begin{array}{l}.78 \\
(.76)\end{array}$ & $\begin{array}{l}-1.18 \\
(.48)^{* * *}\end{array}$ & $\begin{array}{l}-.31 \\
(.76)\end{array}$ & $\begin{array}{l}-1.19 \\
(.48)^{-0 *}\end{array}$ \\
\hline RESOURCE & $\begin{array}{l}-.48 \\
(.88)\end{array}$ & $\begin{array}{l}-.05 \\
(.56)\end{array}$ & $\begin{array}{l}-.51 \\
(.82)\end{array}$ & $\begin{array}{l}-.27 \\
(.56)\end{array}$ \\
\hline SALES & $\begin{array}{c}-2.5 \mathrm{E}-05 \\
(1.5 \mathrm{E}-05)^{\circ}\end{array}$ & $\begin{array}{c}-1.8 \mathrm{E}-105 \\
(7.0 \mathrm{E}-06)^{\cdots}\end{array}$ & $\begin{array}{l}-6.8 \mathrm{E}-06 \\
(1.5 \mathrm{E}-05)\end{array}$ & $\begin{array}{l}-8.8 \mathrm{E}-06 \\
(8.3 \mathrm{E}-06)\end{array}$ \\
\hline RNDINT & $\begin{array}{c}. .26 \\
(.11)^{+* *}\end{array}$ & $\begin{array}{l}-.15 \\
(.09)^{*}\end{array}$ & $\begin{array}{c}-.23 \\
(.11)^{* *}\end{array}$ & $\begin{array}{l}-.11 \\
(.09)\end{array}$ \\
\hline ADVINT & $\begin{array}{c}.07 \\
(.08)\end{array}$ & $\begin{array}{c}.08 \\
(.04)^{\circ}\end{array}$ & $\begin{array}{l}.01 \\
(.07)\end{array}$ & $\begin{array}{c}.06 \\
(.04)^{\prime}\end{array}$ \\
\hline LACKCEXP & $\begin{array}{l}.09 \\
(.45)\end{array}$ & $\begin{array}{c}. .99 \\
(.24)^{* *}\end{array}$ & $\begin{array}{l}-.13 \\
(.45)\end{array}$ & $\frac{-1.03}{(.24)^{* * *}}$ \\
\hline CULTDIST & $\begin{array}{c}-1.19 \\
(.36)^{* * *}\end{array}$ & $\begin{array}{l}-.26 \\
(.21)\end{array}$ & $\begin{array}{l}-1.20 \\
(.38)^{* * *}\end{array}$ & $\begin{array}{l}-.26 \\
(.21)\end{array}$ \\
\hline ACQEXP & $\begin{array}{c}.01 \\
(.05)\end{array}$ & $\begin{array}{l}.05 \\
(.05)\end{array}$ & & \\
\hline JVEXP & & & $\begin{array}{c}-.15 \\
(.07)^{* 4}\end{array}$ & $\begin{array}{c}-.15 \\
(.06)^{* * *}\end{array}$ \\
\hline Constant & $\begin{array}{c}3.60 \\
(1.36)^{\circ \cdot 4}\end{array}$ & $\begin{array}{c}3.46 \\
(.81)^{\cdots}\end{array}$ & $\begin{array}{c}4.49) \\
(1.39)^{\circ * *}\end{array}$ & $\begin{array}{l}3.68 \\
(.81)^{* * *}\end{array}$ \\
\hline -2 Log Likelihood & 70.20 & 144.36 & 66.12 & 139.50 \\
\hline Model $x^{2}$ (d.f.) & $37.15^{* * *}(8)$ & $61.87^{* * *}(8)$ & $41.24^{* * *}(8)$ & $66.72^{-4 *}(8)$ \\
\hline Correct \% & $77.22 \%$ & $79.33 \%$ & $78.48 \%$ & $80.00 \%$ \\
\hline$N$ & 79 & 150 & 79 & 150 \\
\hline
\end{tabular}

Note: Tests of significance (one-rail): *p<.10,**p<.05,***p<.01

Test results of the moderated relationships by product diversification (PRODDIVN) are summarized in Table 6. Since PRODDIVN itself is a binary variable, we formed subgroups accordingly i.e., an expansion was cacegorizerl into the "high" product diversification subgroup when its PRODDIVN value is 1 , and into the "low" product diversification subgroup when its PRODDIVN value is 0.

With respect to ACQEXP, not only the effect was not significant in both subgroups, but also a negative direction of its effect was found in equation II of Table 6, contradicting our prediction. 
On the other hand, supporting Hypothesis 5, JVEXP showed a higher significance level in the "low" product diversification subgroup $(p<.01)$ than in the "high" subgroup $(p<.05)$, with correct signs in both equations III an IV.

\section{DISCUSSION AND CONCLUSION}

Overall, the results show partial support for out RBV-based model of governance choice. Our hypotheses were strongly supported in the joint venture mode, but not in the acquisition mode. Specifically, a firm's prior joint venture experience was found to significantly increase the likelihood of the firm's subsequent choice of a joint venture over an acquisition. Here we emphasize that this effect was significant even after the effects of other factors suggested in the extant literature of governance mode choice, including TCF perspective, were controlled for in the tested models. In addition, for the purpose of testing our RBV-based explanation against the competing explanation of organizational inertia, we hypothesized the moderation effects by uncertainty. In support of our explanation over the inertia hypothesis, the positive relationship between the firm's ptior joint venture experience and the firm's subsequent choice of a joint venture over an acquisition was found to be stronger in low uncertainty than in high uncertainty, and this moderated relationship was robust across all three categories of cxamined uncertainties.

In contrast to the strong support found in the joint venture mode, the data did not support our hypotheses as it pertained to the acquisition mode i.e., a firm's prior acquisition experience did not significantly increase the firm's propensity to choose an acquisition over a joint venture in its subsequent expansion. Also, no significant moderation effects by uncertainty were found.

The lack of empirical support for our hypotheses in the acquisition mode may be due to the fact that acquisitions are often mediated by such external financial institutions as investment banks and brokerage firms that specialize in mergers and acquisitions. In such cascs, important managerial skills necessary for planning acquisitions are not likcly to develop internally within the firm. We expect that, to the extent firms' reliance on external institurions for managerial services is common in acquisition practices, the measure used in our study i.e., number of acquisitions made by the firm may not accurately capture the magnitude of the firm's own managerial resources pertaining to the acquisition mode.

Another conjecture is that the development of mode-specific managerial resources may inherently be less common in acquisitions than in joint ventures due to the differences in management processes. In acquisitions, from the perspective of the acquiring firm, the task of managing the acquired firm is not fundamentally diffetent from the task of managing its own organization in that both assume a unitary hierarchical control. Thus, the transferability of managerial skills from the acquiring firm to the acquired firm may be high. In contrast, the transferability of managerial skills from 
a parent firm to a joint venture may be low because joint ventures exhibit a dual hierarchical control i.e., ownership and control are shared between partners, and managing under a dual hierarchical control can be qualitatively different from managing under a unitary hierarchical control. Therefore, developing mode-specific managerial resources may inherently be more ctitical for the joint venture mode than for the acquisition mode.

An important implication of the findings of this study to the strategy literature is that Penrose's theory provides a useful framework to understand governance choice i.e., a firm's choice of mode reflects the managerial limit to the firm expansion and to the firm's behavior to fully utilize its unused resources. While this way of understanding governance choice behavior is new, we believe it is complementary to the existing discussions in the literature in the following ways.

First of all, an important line of criticism on TCE analysis has been its skewed focus on the cost side of governing relationships through different modes by implicitly assuming an equal level of benefit across the modes (Madhok 1996). In this respect, we view that our Penrosean explanation contributes to the literature by providing a countervailing framework where governance choice is driven by the benefits from each mode. Specifically, central to our model is the comparison of benefits associated with different modes along the following aspects i.e., different potentials for enlarging productive opportunity set for the firm, different potentials for cultivating opportunities in insightful ways, and dynamically, different rates of enlarging and enriching the resource base itself by the continuous development of new resources and capabilities over time. Furthermore, we note all of these bear direct implications to generating economic rents, and thus, firm's comperitive advantage.

Second, we feel that this study's finding of inter-temporal linkage of firm's governance rnode choices contributes to the literature by counterbalancing the static nature of TCE perspective. Our model emphasizes that, for a given activity, the henefits and costs of a particular mude perceived by a firm change over time, not because of the changes in external environmental parameters affecting such benefits and costs, but because of both quancitative and qualitative changes in the firm's managerial resources for different modes over time. Here, we are not arguing that the static benefits and costs of each mode, such as production cost savings and transaction costs, are not an important factor in governance choice. While they do affect individual governance choices, our contention is that the potentials of such static benefits and costs must be assessed in conjunction with the availability of managerial skills and knowledge that are necessary in converting potential benefits into actual ones when the firm actually operates through a chosen mode. We view that such managerial skills and knowledge are a product of an evolutionary process.

Third, while the assumption of opportunism is central to the TCE analysis, it has also been criticized in the literature as being overly narrow, unbalanced, and sometimes unrealistic (Moran and Ghoshal 1996; Kogut and Zander 1992; Madhok 1996). Accordingly, there has been a stream of research attempring to develop an op- 
portunism-independent theory of economic organizations and governance from the knowledge-based perspective of the firm (See Conner 1991; Kogut and Zander 1992, 1996; Conner and Prahalad 1996; Madhok 1996). We believe this study adds value to such stream of research by providing a governance model that docs not sely on the opportunism assumption.

The findings of this study also suggest that future research needs to directly relate mode-specific managerial resources to a firm's competitive advantage. Mode-specific managerial resources may generate economic rents insofar as they exhibit the characteristics of tare, inimitable, and valuable resources (Barney 1991). We argued that mode-specific managerial skills and knowledge are unique firm-specific resources, because they develop over time with firm-specific histories of governance choices, and also because they develop in a socially-embedded way within the management team of a particular firm (Penrose 1959). Also, the development of mode-specific managerial resources is path dependent (Arthur 1989) i.e., past experience with a particular mode enlarges and enriches the future expansion opportunities through the mode. In this sense, the mode-specific managerial resources can be viewed as another source of a firm's competitive advantage. Future research along this line secms worthwhile.

The significance of mode-specific managerial resources found in this study also provides a new conceptual implication to the existing research stream on managerial. resources within RBV (Sce Castanias and Helfat 1991; 1992; Mahoney 1995). Beyond the traditional approach of viewing the construct of managerial resources as a whole in determining a firm's competitive advantage, the findings of this study suggest the usefulness of taking a narrower conceptualization of managerial resources (e.g., managerial resources specific to certain product markets, geographical markets, strategy types, or organizational forms). Based on such fine-grained conceptualization, a plausible line of inquiry may be which types of managerial resources are more appropriate than other types in determining a firm's competitive advantage? And, in which contexts?

Finally, we acknowledge some limitations of this study. The generalizability of our findings is constrained by at least two factors. First, our study is based on the manufacturing sector, thus the findings may not be directly applicable to the service sector. Second, in our study, only two modes i.e., joint ventures and acquisitions, are compared as alternatives. Extending the number of compared modes should provide a richer understanding of the governance mode choice behavior. Another concern we note is the measurement of mode-specific managcrial resources used in this study. While the measure used in this study i.c., counting the number of prior experience in a mode, has the merits of objectivity and data accessibility, as we noted earlier, the rate of managerial resource development may inherently be different across different modes. Future research efforts are needed to address these prohlems. 


\section{REFERENCES}

Agarwal, S. and Ramaswami, S. N. 1992. Choice of Orgarizational Form in Foreign Markets: A Transaction Cost Perspective. Paper presented at the 1992 AlB Annual Meeting, Bnissels, Belgium.

Alchian, A. A., and Demsetz, H. 1972. Production, Information Costs and Economic Organization. American Economic Review 62: $777-95$.

Arrow, K. J. 1974. The Limits of Organization. New York: W. W. Nortun.

Arthur, W. B. 1989. Competing Technologies, Increasing Returns, and Lock-in by Historical Events. Economic Joumal 97: 116-31.

Barkema, H. G., Bell, J. H., and Pennings, J. M. 1996. Foreign Entry, Cultural Barriers, and Learning. Sirategic Management Journal 17: 151-166.

Barney, J. B. 1986. Strategic Factor Markets: Expectations, Luck, and Business Strategy. Management Science 42: 1231-41.

Barney, J. B. 1991. Firm Resources and Sustained Competitive Advantage. Joumal of Management 17: 99-120.

Benito, G. R. G. and Gripsrud, G. 1992. The Expansion of Foreign Direct Investments: Discrete Rational Locacion Choices or A Cultural Learning Process? Joumal of International Business Studies 23 (3): 461-76.

Black, J. A., and Boal, K. B. 1994. Strategic Resources, Traits, Configurations and Paths to Sustainable Competitive Advantage [Special issue]. Strategic Management Joumal 15: $131-48$.

Borys, B., and Jemison, D. B. 1989. Hybrid Arrangements as Strategic Alliances: Theoretical Issues in Organizational Combinations. Academy of Management Review 14: 234-49.

Bower J. L., Bartlett, C. A., Uyterhoeven, H. E., and Walton, R E. 1990. Corning Incorporated: A Network of Alliances. Business Policy: Managing Strategic Processes. New York: Irwin.

Brouthers, K. D. 2002. Institutional, Cultural and Transaction Cost Influences on Entry Mode and Performance. Joumal of International Business Studies 33 (2): 203-21.

Brouthers, K. D. and Brouthers, L. E. 2000. Research Notes and Communications Acquisition or Greenfield Start-up? Institutional, Cultural and Transaction Cost Influences. Strategit Management Joumal 21: 89-97.

Castanias, R. P. and Helfat, C. E. 1991. Managerial Resources and Rents. Joumal of Management 17 (1): 155-71.

Castanias, R. P. and Helfat, C. E. 1992. Managerial and Windfall Rents in the Market for Corporate Control. Joumal of Economic Bebavior and Onganizations 18: 153-84.

Caves, R. E. and Mehra, S. 1986. Entry of Foreign Multinationals into U.S. Manufacturing Industries. In Competition in Global Industries, ed. M. Porter. Boston: Harvard Business School Press.

Chen, S-F. and Hennart, J-F. 2002. Japanese Investors' Chuice of Joint Ventures versus Wholly-owned Subsidiaries in the US: The Role of Market Barriers and Firm Capabilities. Joumal of International Business Studies 33 (1): 1-18.

Cho, K. R. and Padmanabhan, P. 1992. Acquisition versus New Venture: The Choice of Foreign Establishment Mode. Paper presented at the 1992 AIB Annual Meeting, 
Brussels, Belgium.

Conner, K. R. 1991. A Historical Comparison of Resource-based Theory and Five Schools of Thought within Industrial Organization Economics: Do We Have a New Theory of the Firm? Joumal of Management 17: 121-54.

Conner, K. R. and Prahalad, C. K. 1996. A Resource-based Theory of the Firm: Knowledge versus Opportunism. Organization Science 7: 477-501.

Davis, P. S., Desai, A. B. and Francis, J. D. 2000. Mode of International Entry: An Isomorphism Perspective. Journal of Intemational Business Studies 31 (2): 239-58.

Dierickx, 1., and Cool, K. 1989. Asset Stock Accumulation and Sustainability of Competitive Advantage. Management Sience 35: 1504-11.

Dubin, M. 1975. Foreign Acquisitions and the Spread of the Multinational Firm. D. B. A. thesis, Graduate School of Business Administration, Harvard University.

Gatignon, H. and Anderson, E. 1988. The Multinational Corporation's Degree of Control over Foreign Subsidiaries: An Empirical Test of a Transaction Cost Explanation. Joumal of Law, Economics, and Organization 4: 305-36.

Gomes-Casseres, B. 1989. Ownership Structure of Foreign Subsidiaries: Theory and Evidence. Joumal of Economic Behavior and Organizations 11: 1-25.

Granovetter, M. 1985. Fconomic Action and Social Srructure: The Problem of Embeddedness. American Joumal of Sociology 91: 481-510.

Grant, R. M. 1995. Contemporany Strategy Analysis. Cambridge, MA: Blackwell.

Hannan, M. T. and Freeman, J. H. 1977. The Population Ecology of Organizations. Americon Joumal of Socialogy 83: 929-64.

Harzing, A-W. 2002. Acquisitions versus Grecnficld Investment: International Strategy and Management of Entry Modes. Strategic Management Journal 23: 211-27.

Hennart, J-F. 1991. The Transaction Costs Theory of Joint Ventures: An Empirical Study of Japanese Subsidiaries in the Lnited States. Management Science 37: 483-97.

Hennart, J-F. and Reddy, S. B. 2000. Research Notes and Communications Digestibility and Asymmetric Information in the Choice between Acquisitions and Joint Ventures: Where's the Beef? Strategic Management Joumal 21: 191-3.

Herrmann, P. and Datta, D. K. 2002. CEO Successor Characteristics and the Choice of Foreign Market Entry Mode: An Empirical Study. Journal of International Business Studies 33 (3): 551-69.

Hofstede, G. 1980. Culture's Comsequences: Intemational Differences in Wirk-Related Values. Beverly Hills, CA: Sage.

Hofstede, G. 1991. Cultures and Organizations. Bcrkshire, U.K.: MoGraw-Hill.

Hunt, S. D. 1997. Competing through Relationships: Grounding Relationship Marketing in Resource-advantage Theory. Jaumal of Marketing Managment 13: 431-45.

Johanson, J. and Vahlne, J.-E. 1977? The Internationalization Process of the Firm: A Model of Knowledge Development and Increasing Foreign Market Commitments. Journal of International Business Studies 8: 23-32.

Kellet, J. 1997. GIE Hires Deal Maker Santillana. The Wall Stret Joumal, January 20.

Kerber, R. 1997. Merger Specialist Hired by Polaroid in Bid for Growth. The Wall Street Journal, February 6.

Killing, J. P. 1983. Strategies for Joint Venture Success. New York: Praeger. 
Klein, B., Crawford, R G., and Alchian, A. A. 1978. Vertical Integration, Appropriable Rents and the Competitive Contracting Process. Joumal of Law and Economito 21: 297-326.

Kogut, B. and Singh, H. 1988. The Effect of National Culture on the Choice of Entry Mode. Journal of International Business Studic: Fall: 411-32.

Kogut, B. and Zander, U. 1992. Knowledge of the Firm, Combinative Capabilities, and the Replication of Technology. Organization Science 4: 383-97.

Kogut, B. and Zander, U. 1996. What Firms Do? Coordination, Identity, and Learning. Organization Science 7: 502-18.

Koh, J. and Venkatraman, N. 1991. Joint Venture Formations and Stock Market Reactions: An Assessment in the Information Technology Sector. Academy of Management Joumal 34: $869-92$.

Madhok, A. 1996. The Organization of Economic Activity: Transaction Costs, Firm Capabilities, and the Nature of Governance. Organization Science 7: 577.90.

Mahoney, J. T. and Pandian, J. R 1992. The Resource-based View within the Conversation of Strategic Management. Strategic Management Joumal 13: 363-80.

Mahoney, J. T. 1995. The Management of Resources and the Resource of Management. Journal of Business Research 33: 91-101.

Moran, P. and Ghoshal, S. 1996. Theories of Economic Organization: The Case for Realism and Balance. Academy of Management Review 21: 58-72.

Morrison, D. 1974. Discriminant Analysis. In Handbook of Marketing Researb, cd. R Ferber. New York: Wiley.

Neter, J., Wasserman, W., and Kutner, M. H. 1989. Applied Linear Regression Models. Homewood, IL: Irwin.

North, D. C. 1990. Institutions, Institutional Change, and Economic Performance. Cambridge, UK: Cambridge University Press.

Norusis, M. J. 1993. SPSS for Windous Advanced Statistics Release 6.0. Chicago, IL: SPSS Inc.

Oliver, C. 1997. Sustainable Competitive Advantage: Combining Institutional and Resource-based Views. Strategic Management Joumal 18: $697-713$.

Penrose, E. T. 1959. The Theory of the Grouth of the Firm. Oxford, U.K. Basil Blackwell.

Peteraf, M. A. 1993. The Cornerstones of Competitive Advantage: A Resource-based View. Strategic Management Joumal 14 (3): 179-92.

Polanyi, M. 1962. Personal Knowledge: Touard a Prst-Critical Pbilosopby. New York: Harper Torchbroks.

Reed, R, and DeFillippi, R. J. 1990. Causal Ambiguity, Barriers to Imitation, and Sustainable Competitive Advantage. Acadimy of Management Review 15: 88-117.

Root, F. J. 1987. Entry Strategies for Intemational Markess. Lexington, MA: Lexington Books.

Rumelt, R.P. 1984. Toward a Strategic Theory of the Firm. In Competitive Strategic Management, ed. R. Lamb. Englewood Cliffs, NJ: Prentice-Hall.

Rumclt, R P. 1987. Theory, Strategy, and Entrepreneurship. In The Competitive Challenge, cd. D. J. Teece. Cambridge, MA: Ballinger Publishing.

Slater, M. 1980. The Managerial Limitation to the Growth of Firms. The Fconomic Journal 90: $520-8$.

Stopford, J. and Wells, L. 1972. Managing the Mulinational Enterprise: Organization of 
the Form and Chnersbip of the Subsidiaries. New York: Basic Books.

Teece, D. J. 1981. The Market for Know-how and the Efficient International Transfer of Technology. Annals of the American Academy of Political and Social Science November: $81-96$.

Uzzi, B. 1996. The Sources and Consequences of Embeddedness for the Economic Performance of Organizations: The Network Effect. American Sociological Review 61: 674-98.

Venkatraman, N. 1989. The Concept of Fit in Strategy Research: Toward Verbal and Statistical Correspondence. Academy of Management Review 14 (3): 423-44.

Wernerfelt, B. 1984. A Resource-based View of the Firm. Strategic Management Jaumal 5 (2): $171-80$.

Williamson, O. 1985. The Economic Institutions of Capitalism. New York: Free Press.

Wilson, B. 1980. The Propensity of Multinational Companies to Expand through Acquisitions. Joumal of International Business Studies 12 (Spring/Summer): 59-65. 